\title{
OPTIMASI KESESUAIAN ALAT TANGKAP PADA IKAN MENGGUNAKAN METODE PERBANDINGAN EKSPONENSIAL (MPE)
}

\author{
Shafira Anggriati ${ }^{1}$,Yosep Agus Pranoto ${ }^{2}$, Nurlaily Vendyansyah ${ }^{3}$ \\ Program Studi Teknik Informatika S1, Fakultas Teknologi Industri \\ Institut Teknologi Nasional Malang, Jalan Raya Karanglo km 2 Malang, Indonesia \\ 1618035@scholar.itn.ac.id
}

\begin{abstract}
ABSTRAK
Penentuan alat tangkap yang cocok bagi masyarakat Prigi di Kabupaten Trenggalek merupakan permasalahan yang penting karena ikan adalah sumber pendapatan utama para nelayan di prigi. permasalahannya adalah pemilihan alat tangkap ikan bagi nelayan di prigi masih kurang efektif. dalam pemilihan alat tangkap ikan harus di sesuaikan dengan kondisi yang dialami nelayan seperti kemampuan ekonomi dalam pembelian alat tangkap ikan, tingkat selektifitas yang diinginkan nelayan, nelayan juga perlu mengetahui kualitas hasil tangkapan ikan dari alat tangkap, ataupun tingkat keamanan alat tangkap yang akan digunakan.

Pada penelitian ini menggunakan Metode Perbandingan Eksponensial untuk menentukan alat tangkap ikan yang disesuaikan dengan kondisi nelayan di Pelabuhan Perikanan Nusantara Prigi Trenggalek. Berdasarkan hasil pengujian yang telah dilakukan peneliti menggunakan data pada tahun 2018, didapatkan 4 alternatife yaitu pancing tonda, pancing ulur, payang, jarring insang, dan 4 kriteria yaitu tingkat selektifitas dengan sub kriteria tinggi dan rendah, tingkat keamanan dengan sub kriteria aman dan kurang aman, kualitas tangkapan dengan sub kriteria bagus dan sedang, harga alat tangkap dengan sub kriteria murah dan mahal. Perhitungan menggunakan Metode Perbandingan Ekponensial digunakan untuk menentukan alternatif yang akan ditawarkan dalam penyelesaian masalah. Nilai alternatif yang ditawarkan nantinya tergantung pada pemberian bobot nilai kriteria.

Dari hasil pengujian sistem browser dengan menggunakan 3 browser yaitu v3.2.2 (MF) mozila firefox 63.0.2 (32bit), (ME) Microsoft Edge, dan Internet Explorer(IE) 100\% dapat berjalan browser sesuai rancangan kebutuhan, dari hasil perhitungan menggunakan Metode Perbandingan Eksponensial dengan menggunakan data Ikan alu-alu, tingkat selektifitas tinggi, kualitas tangkapan bagus, dan harga murah alternatif yang di tawarkan adalah alat tangkap pancing ulur dan data ikan albakora dengan tingkat selektifitas tinggi, kualitas tangkapan bagus, dan harga murah alternatif yang ditawarkan adalah alat tangap pancing tonda.
\end{abstract}

Kata kunci : Sistem Pendukung Keputusan(SPK), Metode Perbandingan Eksponensial (MPE), Alat tangkap Ikan.

\section{PENDAHULUAN}

\subsection{Latar Belakang}

Prigi merupakan desa yang masyarakatnya banyak berprofesi sebagai nelayan. Pelabuhan Perikanan Nusantara Prigi pada awalnya merupakan desa pantai tradisional yang berlokasi di teluk prigi. dengan berjalannya waktu kini prigi menjadi salah satu pelabuhan perikanan di Indonesia, Pelabuhan Perikanan Nusantara Prigi memiliki beragam ikan dan berbagai macam jenis alat tangkap.

Penentuan alat tangkap yang cocok bagi masyarakat Prigi di Kabupaten Trenggalek merupakan permasalahan yang penting karena ikan adalah sumber pendapatan utama para nelayan di Prigi. Permasalahannya adalah dalam pemilihan alat tangkap ikan bagi nelayan di Prigi masih kurang efektif. Karena dalam pemilihan alat tangkap harus di sesuaikan dengan kondisi yang dialami nelayan seperti kemampuan ekonomi dalam pembelian alat tangkap ikan, tingkat selektifitas yang diinginkan nelayan, kualitas hasil tangkapan dari alat tangkap ikan, ataupun tingkat keamanan alat tangkap yang akan digunakan.

Pada tahun 2013 dengan penelitihan berjudul Implementasi Metode Perbandingan Eskponensial dalam penentuan Asisten Laboratorium (Studi Kasus: Di Lab.
FKOM UNIKU) yang di teliti oleh Nurhayati untuk menenukan asisten Laboratorium dilakukan dengan perangkingan dari nilai terbesar sampai nilai terkecil. Dalam Penelitian ini Nurhayati telah berhasil merancang dan mengimplementasikan Metode Perbandingan Eksponensial (MPE) menggunakan bahasa pemrograman PHP dan MySQL, dimana sistem ini berhasil mencapai tujuannya yaitu mampu membantu pihak Lab FKOM UNIKU dalam menentukan Aslab yang kompeten sesuai bidang keilmuannya. (Nurhayati 2015)

Berdasarkan masalah yang sudah di deskripsikan, penulis bermaksut membuat skripsi optimasi kesesuaian alat tangkap pada ikan menggunakan metode perbandingan eksponensial (mpe) untuk menentukan alternatif yang ditawarkan dalam penyelesaian masalah, nilai alternatife yang ditawarkan nantinya tergantung pada pemberian bobot nilai kriteria. kriteria yang digunakan dalam sistem ini adalah tingkat selektifitas alat tangkap ikan, kualitas hasil tangkapan, tingkat keamanan alat tangkap, dan harga alat tangkap.

Metode Perbandingan Exponensial (MPE) adalah salah satu metode dari Decision Suport System (DSS) yang digunakan untuk menentukan urutan prioritas alternatif keputusan dengan kriteria jamak. MPE sangat cocok untuk penilaian skala ordinal (contoh sangat baik, 
baik, kurang, sangat kurang). Hasil MPE akan lebih kontras dari pada hasil Bayes. Metode Perbandingan Eksponensial mempunyai keuntungan dalam mengurangi bias yang mungkin terjadi dalam analisis. Nilai skor yang menggambarkan urutan prioritas menjadi besar (fungsi eksponensial) ini mengakibatkan urutan prioritas alternatif keputusan lebih nyata (Nurhayati 2015).

\subsection{Rumusan Masalah}

Berdasarkan permasalahan yang di paparkan di latar belakang dapat dirumuskan sebagai berikut:

1. Bagaimana menentukan alternatif alat tangkap ikan yang sesuai dengan kondisi nelayan di pelabuhan perikanan nusantara prigi ?

2. Bagaimana merancang sistem untuk menentukan alat tangkap ikan dengan menggunakan metode perbandingan eksponensial?

3. Bagaimana menerapkan metode perbandingan eksponensial pada aplikasi berbasis web ?

\subsection{Tujuan}

Terdapat beberapa tujuan dari pembuatan aplikasi ini sebagai berikut :

1. Sistem ini dibangun dengan menggunakan Metode Perbandingan Eksponensial untuk menghitung nilai keputusan dalam menentukan alternatif pemilihan alat tangkap ikan.

2. Data yang digunakan pada pengembangan sistem pendukung keputusan untuk penentuan alat tangkap ikan merupakan data langsung dari Pelabuhan Perikanan Nusantara Prigi Trenggalek tahun 2018.

3. Untuk mengembangkan sistem dengan Metode Perbandingan Eksponensial (MPE) dalam rangka penentuan alat tangkap yang cocok di Pelabuhan Perikanan Nusantara Prigi Trenggalek.

\subsection{Batasan Masalah}

Berdasarkan pembuatan sistem pendukung keputusan ini terdapat beberapa batasan dalam pembuatan yaitu sebagai berikut:

1. Data yang digunakan pada pengembangan sistem ini merupakan data langsung dari Pelabuhan Perikanan Nusantara Prigi Trenggalek tahun 2018.

2. Sistem ini dirancang menggunakan Metode Perbandingan Eksponensial (MPE).

3. Platform yang digunakan berbasis web.

4. Bahasa pemrograman yang digunakan adalah PHP versi 7 dan database yang digunakan adalah Mysq1 5.7

\subsection{Manfaat}

Terdapat beberapa manfaat dari pembuatan aplikasi ini sebagai berikut :

1. Dapat membantu nelayan di Pelabuhan Perikanan Nusantara Prigi Trenggalek.

2. Memberikan alternatife keputusan dalam pemilihan alat tangkap yang sesuai dengan kondisi nelayan.
3. Untuk penulis, membantu memahami Metode Perbandingan Eksponensial (MPE) pada sistem pendukung keputusan.

\section{TINJAUAN PUSTAKA}

\subsection{Penelitihan Terkait}

Pada tahun 2013 dengan penelitihan berjudul Implementasi Metode Perbandingan Eksponensial dalam penentuan Asisten Laboratorium (Studi Kasus: Di Lab. FKOM UNIKU) yang di teliti oleh Nurhayati untuk menenukan asisten Laboratorium dilakukan dengan perangkingan dari nilai terbesar sampai nilai terkecil. Dalam Penelitian ini Nurhayati telah berhasil merancang dan mengimplementasikan Metode Perbandingan Eksponensial (MPE) menggunakan bahasa pemrograman PHP dan MySQL, dimana sistem ini berhasil mencapai tujuannya yaitu mampu membantu pihak Lab FKOM UNIKU dalam menentukan Aslab yang kompeten sesuai bidang keilmuannya. (Nurhayati 2015)

Menurut penelitihan Desi Wira Swastika yang berjudul "Analisis Pendapatan Nelayan Pantai Prigi Desa Tasikmadu Kecamatan Watulimo Kabupaten Trenggalek", pada penelitihan ini di jabarkan bahwa masyarakat di kawasan seitar pantai mengandalkan hasil tangkap laut ikan sebagai salah satu mata pencaharian utama dalam hal perekonomian, namun sebagian besar masyarakat hanya sebagai buruh nelayan, mereka bekerja kepada orang yang mempunyai kapal layar seperti penarik jaring ikan dari tengah laut ke tepi pantai dengan menggukan cara tradisional yaitu menarik dengan tenaga manusia. (Desi Wira Swastika 2017)

Pada penelitihan yang berjudul "Fungsi tempat pelelangan ikan pelabuhan nusantara prigi desa tasikmadu,kecamatan watulimo, kabupaten trenggalek" yang dilakukan oleh nanda rilo prambudi , dijelaskan bahwa penghasilan nelayan di prigi tergantung pada cuaca dan musim. Bagi nelayan musim merupakan hal yang sangat penting karena menjadi faktor banyak dan sedikitnya hasil tangkapan. Secara umum, pendapatan nelayan sangat fluktuatif dari hari ke hari selain kondisi alam pendapatan juga di tentukan oleh produktifitas dari alat tangkap. (Nanda Rilo Prambudi 2017)

Pada tahun 2017 dengan penelitihan berjudul Sistem Pendukung Keputusan untuk Menentukan Alat Tangkap yang Sesuai bagi Nelayan di Madura Menggunakan Metode AHP-TOPSIS yang di teliti oleh Heru Lumaksono dan Hozairi untuk menenukan alat tangkap di madura menggunakan 6 kriteria yaitu Sekektivitas, Produktivitas, Dampak lingkungan, Kualitas Hasil Tangkapan, Tidak membahayakan, Biaya dan 6 alternatif Pancing, Bubu, Bagan Apung, Payang, Jaring insang, Pukat cincin. (Heru Lumaksono 2017)

\subsection{Sistem Pendukung Keputusan}

Sistem pendukung keputusan adalah suatu sistem informasi spesifik yang ditunjukkan untuk membantu manajemen dalam mengambil keputusan yang berkaitan 
dengan persoalan yang bersifat semi terstruktur. Sistem inin memiliki fasilitas untuk menghasilkan berbagai alternatif yang secara interaktif digunakan oleh pemakai.

Komponen - komponen dalam sistem pendukung keputusan :

1. Data management, mengandung data yang relevan untuk berbagai situasi dan diatur oleh software DBMS (Database Management Systems)

2. Model management, melibatkan model finansial, statistical, management science, atau berbagai model kuantitatif lainnya, sehingga dapat memeberikan kemampuan analitis dan manajemen software yang diperlukan pada sistem.

3. Communication, pengguna dapat berkomunikasi dan memberikan perintah pada DSS melalui sub menu sistem ini.

4. Knowledge, Subsistem optional ini dapat mendukung sub sistem lain atau bertindak sebagai komponen yang berdiri sendiri. (Diana 2018)

\subsection{Metode Perbandingan Eksponensial}

Metode Perbandingan Exponensial (MPE) adalah salah satu metode dari Decision Suport System (DSS) yang digunakan untuk menentukan urutan prioritas alternatif keputusan dengan kriteria jamak. Dengan perhitungan secara eksponensial, perbedaan nilai antara kriteria dapat dibedakan tergantung kepada kemampuan orang yang menilai. Selain itu MPE merupakan salah satu metode pengambilan keputusan yang mengkuantifikasikan pendapat seseorang atau lebih dalam skala tertentu. Teknik ini digunakan untuk membantu individu pengambil keputusan untuk menggunakan rancang bangun model yang terdefinisi dengan baik pada tahapan proses. MPE akan menghasilkan nilai alternatif yang perbedaannya lebih kontras. (Prof. Dr. Ir. Marimin 2004)

Keterangan: Total Nilai $\left(T N_{i}\right)=\sum_{j=1}^{m}\left(R K_{i j}\right)^{T K K j} \ldots$..Persamaan 1

$\mathrm{TNi}=$ Total nilai alternatif $\mathrm{ke}-\mathrm{i}$

$\mathrm{RKij}=$ Derajat kepentingan relatif kriteria

ke-j pada

Pilihan keputusan ke-i

$\mathrm{TKKj}=$ Derajat kepentingan kriteria

keputusan ke-j

TKKJ $>0$; bulat

\section{METODE PENELITIAN}

\subsection{Blok Diagram User}

Pada Diagram Sistem User dapat di jelaskan bahwa User terhubung ke internet terlebih dahulu kemudian mengakses website selanjutnya User dapat mengakses data berupa data informasi ikan dan alat tangkap. pada Gambar 1 dapat diketahui bahwa User dapat mengakses menu penentuan alat tangkap selanjutnya dilakukan perhitungan menggunkan metode MPE. Hasil perhitungan adalah informasi perangkingan yang dapat di akses user hasil perangkingan digunakan untuk penunjang keputusan user dalam memilih alat tangkap ikan.

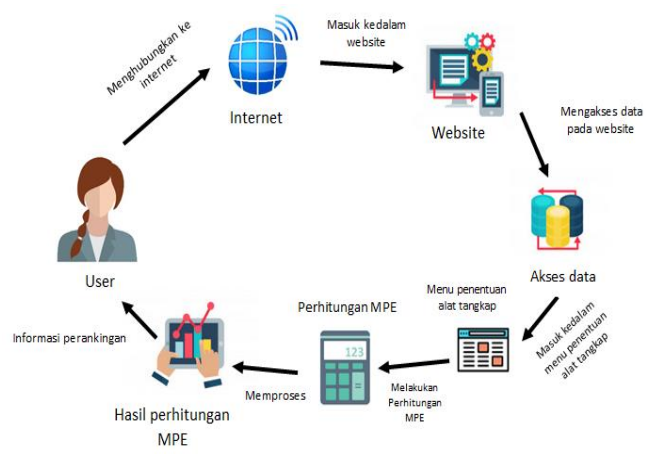

Gambar 1 Blok diagram user

\subsection{Blok Diagram Admin}

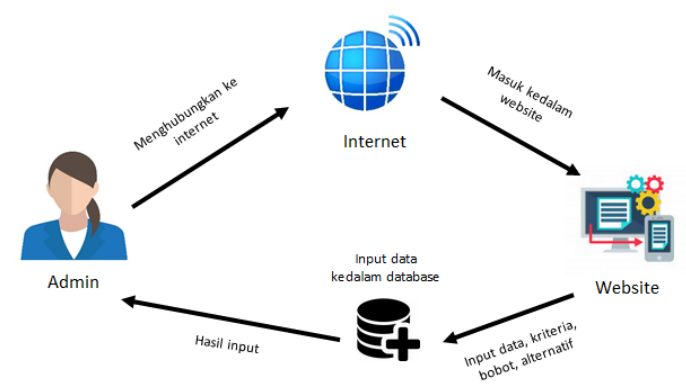

Gambar 2 Blok diagram admin

Pada Diagram Sistem Admin dapat di jelaskan bahwa admin terhubung ke internet terlebih dahulu kemudian mengakses website selanjutnya admin login. Dapat dilihat pada Gambar 2 bahwa admin dapat input data, kriteria, bobot, maupun alternatif. keluaran dari input adalah hasil input yang nantinya digunankan untuk perhitungan optimasi kesesuaian alat tangkap pada ikan dengan menggunakan metode MPE.

\subsection{Struktur Menu}

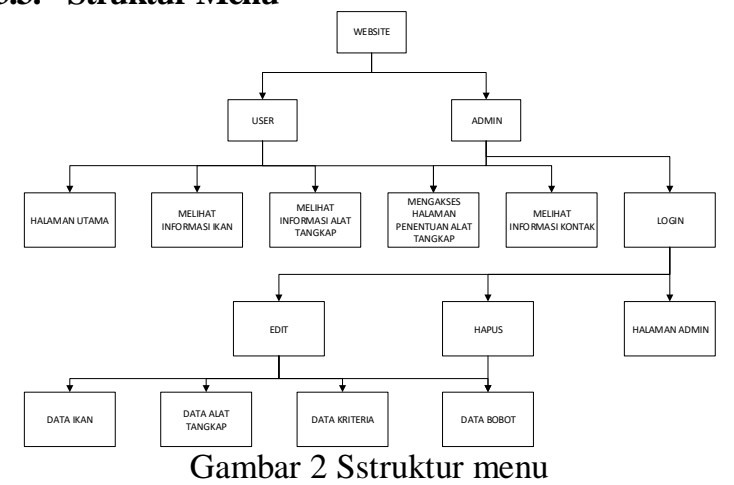

Gambar 2 Struktur Menu yang sudah digambarkan di atas maka dapat dijelaskan bahwa User hanya bisa melihat halaman informasi ikan , halaman informasi alat tangkap, dan halaman penentuan alat tangkap ikan sedangkan untuk admin bisa melihat informasi ikan, informasi alat tangkap, mengakses halaman penentuan alat tangkap ikan serta tambah, edit, hapus informasi ikan, alat tangkap dan mengubah bobot kriteria maupun alternatif. 


\subsection{Flowchart Sistem}

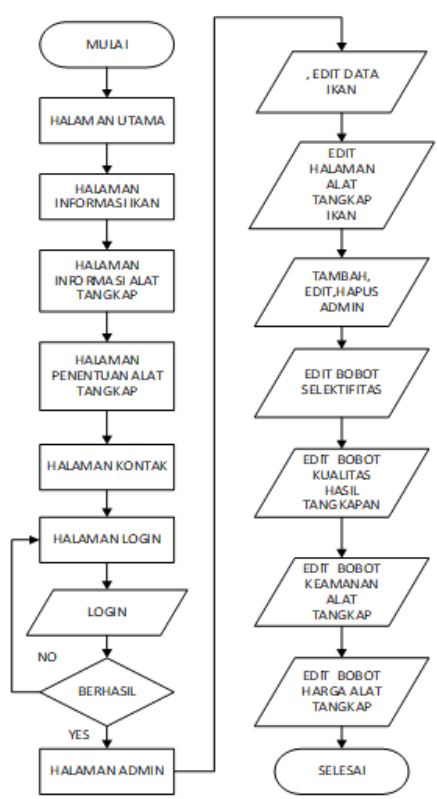

Gambar 3 Flowchart Sistem

Dapat dilihat pada Gambar 3 dapat diketahui halaman awal adalah halaman utama, user dapat mengakses halaman informasi ikan, halaman informasi alat tangkap, kontak, halaman untuk penentuan alat tangkap dan halaman login jika login gagal maka tetap di halaman tersebut jika login berhasil maka akan pindah ke halaman admin. selanjutnya admin dapat memasukkan data ikan, alat tangkap ikan, bobot, dan registrasi admin baru.

\subsection{Flowchart Metode}

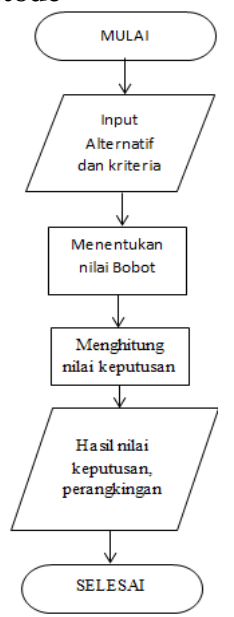

Gambar 4 Flowchart Metode

Pada Flowchart Metode Perbandingan Eksponensial (MPE) dapat jelaskan langkah pertama dalam Flowchart Metode Perbandingan Eksponensial (MPE) untuk penentuan alat tangkap di PPN prigi adalah memasukkan nilai alternatif dan kriteria yang disusul dengan memasukkan nilai bobot, selanjutnya dilakukan perhitungan menggunakan metode MPE tiap alternatif sesuai dengan kriteria yang di masukkan dan hasilnya adalah perangkingan alternatif .

\subsection{DFD Level 0}

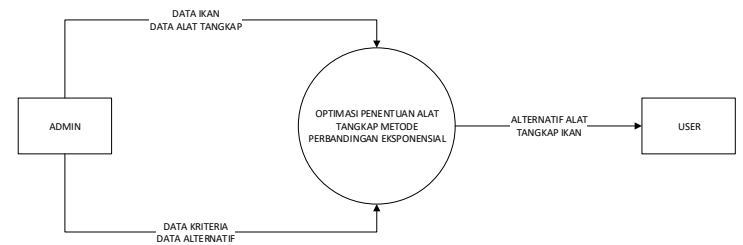

Gambar 7 Rancangan DFD Level 0

Pada Gambar 7 dapat diketahui bahwa admin menambahkan data ikan, alat tangkap, kriteria,dan data alternatif selanjutnya data yang sudah disimpan akan masuk pada proses optimasi kesesuaian alat tangkap ikan menggunakan metode perbandingan eksponensian, dari proses akan keluar hasil berupa alternatif alat tangkap ikan yang selanjutnya diterima oleh user untuk memilih alat tangkap ikan.

\subsection{DFD Level 1}

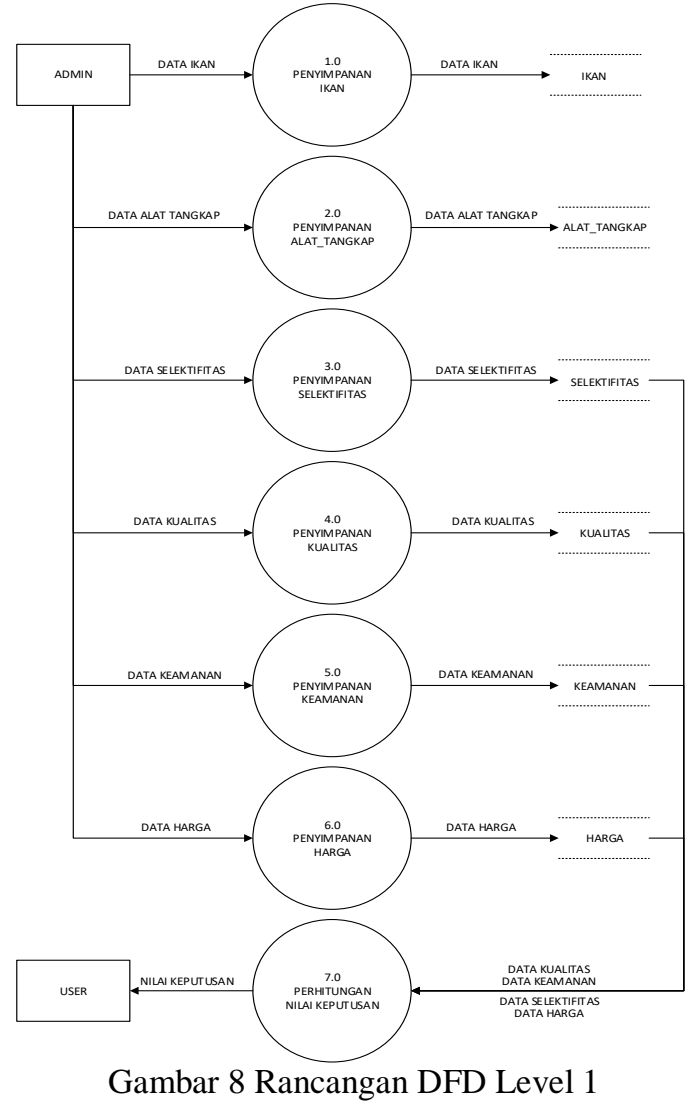

Pada Gambar 8 dapat dilihat proses 1.0 admin menambahkan data ikan masuk ke proses penyimpanan data ikan dan disimpan pada tabel ikan, pada proses 2.0 admin menambahkan data alat tangkap ikan masuk ke proses penyimpanan data alat tangkap ikan dan disimpan pada tabel alat tangkap ikan, pada proses 3.0 admin menambahkan data selektifitas masuk ke proses penyimpanan data selektifitas dan disimpan pada tabel selektifitas, pada 
proses 4.0 admin menambahkan data kualitas masuk ke proses penyimpanan data kualitas dan disimpan pada tabel kualitas, pada proses 5.0 admin menambahkan data keamanan masuk ke proses penyimpanan data keamanan dan disimpan pada tabel keamanan.

\subsection{Entity Relationship Diagram (ERD)}

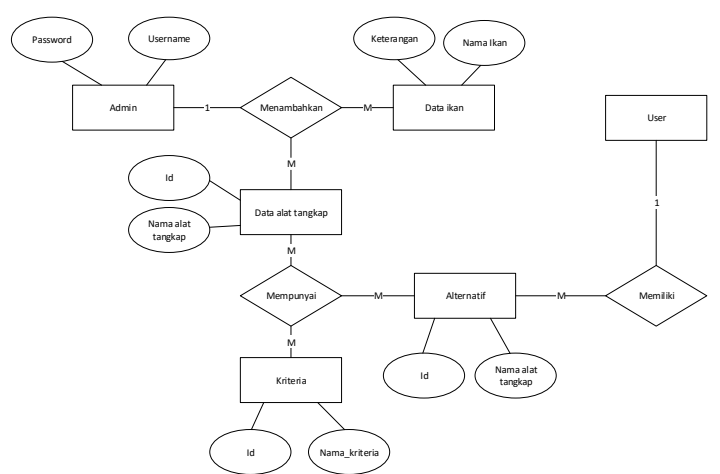

Gambar 8 Rancangan ERD

Pada Gambar 8 dapat diketahui bahwa admin mempunyai atribut Password dan Username untuk login ke sistem selanjutnya admin dapat menambahkan data ikan dengan atribut id,nama ikan dan data alat tangkap dengan atribut id,nama alat tangkap. Pada entitas alat tangkap mempunyai kriteria alat tangkap dengan atribut id,nama kriteria dan alternatif dengan atribut id, nama alat tangkap, selanjutnya user yang mengakses sistem memiliki alternatif alat tangkap ikan berupa atribut id dan nama alat tangkap yang akan digunakan.

\subsection{Perhitungan Metode Perdandingan Eksponensial}

Perhitungan algoritma Metode Perbandingan Eksponensial penulis mengambil data 1 tahun yaitu pada tahun 2018. Data yang diambi 2 data dari hasil tangkapan dari total 50 data hasil tangkapan ikan di Prigi. Dengan 2 data sampel dilakukan perhitungan sesuai dengan algoritma Metode perbandingan eksponensial. Untuk langkah - langkah perhitungan dapat dilihat sebagai berikut:

1. Langkah pertama adalah menyiapkan data hasil tangkapan. Dimana penulis menggunakan 2 data hasil tangkapan yang di tunjukkan pada Tabel 1 . Dan 2

Tabel 1. Data Hasil Hangkapan Ikan Alu - Alu pada tahun 2018

\begin{tabular}{|c|c|}
\hline Jenis Alat Tangkap & Hasil Tangkapan \\
\hline Pancing Ulur & 955 \\
\hline Pancing Tonda & 8 \\
\hline Payang & 0 \\
\hline Jaring Insang & 19 \\
\hline Pukat Cincin & 9 \\
\hline
\end{tabular}

Tabel 2. Data Hasil Hangkapan Ikan Albakora pada tahun 2018

\begin{tabular}{|c|c|}
\hline Jenis Alat Tangkap & Hasil Tangkapan \\
\hline Pancing Ulur & 0 \\
\hline Pancing Tonda & 10799 \\
\hline Payang & 0 \\
\hline Jaring Insang & 689 \\
\hline Pukat Cincin & 0 \\
\hline
\end{tabular}

2. Langkah selanjutnya adalah Normalisasi hasil tangkapan ikan seperti table 3 dan 4

Tabel 3. Hasil Normalisasi Ikan Alu-Alu

\begin{tabular}{|c|c|}
\hline $\begin{array}{c}\text { Jenis Alat } \\
\text { Tangkap }\end{array}$ & Hasil Normalisasi \\
\hline Pancing Ulur & 1 \\
\hline Pancing Tonda & 3 \\
\hline Payang & 1 \\
\hline Jaring Insang & 1 \\
\hline Pukat Cincin & 1 \\
\hline
\end{tabular}

Tabel 4. Hasil Normalisasi Ikan Albakora

\begin{tabular}{|c|c|}
\hline $\begin{array}{c}\text { Jenis Alat } \\
\text { Tangkap }\end{array}$ & Hasil Normalisasi \\
\hline Pancing Ulur & 3 \\
\hline Pancing Tonda & 1 \\
\hline Payang & 1 \\
\hline Jaring Insang & 1 \\
\hline Pukat Cincin & 1 \\
\hline
\end{tabular}

3. Perhitungan Nilai Keputusan Ikan Alu - Alu dan albakora untuk kondisi tingkat selektifitas tinggi, kualitas hasil tangkapan bagus, tingkat keamanan aman, dan harga murah seperti pada table 5 dan 6

Tabel 5 Perhitungan Nilai Selektifitas Ikan Alu - Alu

\begin{tabular}{|c|c|c|c|c|c|}
\hline $\begin{array}{c}\text { Alat } \\
\text { tangkap }\end{array}$ & selektifitas & kualitas & keselamatan & harga & Total \\
\hline $\begin{array}{c}\text { Pancing } \\
\text { ulur }\end{array}$ & 1 & 1 & 2 & 2 & 10 \\
\hline $\begin{array}{c}\text { Pencing } \\
\text { tonda }\end{array}$ & 3 & 1 & 2 & 2 & 36 \\
\hline payang & 1 & 2 & 2 & 2 & 13 \\
\hline $\begin{array}{c}\text { Jaring } \\
\text { insang }\end{array}$ & 1 & 2 & 1 & 1 & 7 \\
\hline $\begin{array}{c}\text { Pukat } \\
\text { cincin }\end{array}$ & 1 & 2 & 1 & 1 & 10 \\
\hline
\end{tabular}

Tabel 6 Perhitungan Nilai Selektifitas Ikan Albakora

\begin{tabular}{|c|c|c|c|c|c|}
\hline $\begin{array}{c}\text { Alat } \\
\text { tangkap }\end{array}$ & selektifitas & kualitas & keselamatan & harga & Total \\
\hline $\begin{array}{c}\text { Pancing } \\
\text { ulur }\end{array}$ & 1 & 1 & 2 & 2 & 10 \\
\hline $\begin{array}{c}\text { Pencing } \\
\text { tonda }\end{array}$ & 3 & 1 & 2 & 2 & 36 \\
\hline payang & 1 & 2 & 2 & 2 & 13 \\
\hline $\begin{array}{c}\text { Jaring } \\
\text { insang }\end{array}$ & 1 & 2 & 1 & 1 & 7 \\
\hline $\begin{array}{c}\text { Pukat } \\
\text { cincin }\end{array}$ & 1 & 2 & 1 & 1 & 10 \\
\hline
\end{tabular}


4. Perangkingan tiap alternatif yang sudah dihitung nilai keputusannya seperti pada table 7 dan 8 .

Tabel 7 Hasil Perangkingan Ikan Alu-alu

\begin{tabular}{|c|c|c|c|c|c|c|}
\hline $\begin{array}{c}\text { Alat } \\
\text { tangkap }\end{array}$ & $\begin{array}{c}\text { selekt } \\
\text { ifitas }\end{array}$ & $\begin{array}{c}\text { Kual } \\
\text { itas }\end{array}$ & $\begin{array}{c}\text { kesela } \\
\text { matan }\end{array}$ & Harga & total & Rank \\
\hline $\begin{array}{c}\text { Pancing } \\
\text { ulur }\end{array}$ & 3 & 1 & 2 & 2 & 36 & 1 \\
\hline $\begin{array}{c}\text { Pencing } \\
\text { tonda }\end{array}$ & 1 & 1 & 2 & 2 & 10 & 3 \\
\hline Payang & 1 & 2 & 2 & 2 & 13 & 2 \\
\hline $\begin{array}{c}\text { Jaring } \\
\text { insang }\end{array}$ & 1 & 2 & 1 & 1 & 7 & 4 \\
\hline $\begin{array}{c}\text { Pukat } \\
\text { cincin }\end{array}$ & 1 & 2 & 1 & 1 & 10 & 3 \\
\hline
\end{tabular}

Tabel 8 Hasil Perangkingan Ikan Albakora

\begin{tabular}{|c|c|c|c|c|c|c|}
\hline $\begin{array}{c}\text { Alat } \\
\text { tangkap }\end{array}$ & $\begin{array}{c}\text { selekt } \\
\text { ifitas }\end{array}$ & $\begin{array}{c}\text { Kual } \\
\text { itas }\end{array}$ & $\begin{array}{c}\text { kesela } \\
\text { matan }\end{array}$ & harga & Total & Rank \\
\hline $\begin{array}{c}\text { Pancing } \\
\text { ulur }\end{array}$ & 1 & 1 & 2 & 2 & 10 & 3 \\
\hline $\begin{array}{c}\text { Pencing } \\
\text { tonda }\end{array}$ & 3 & 1 & 2 & 2 & 36 & 1 \\
\hline Payang & 1 & 2 & 2 & 2 & 13 & 2 \\
\hline $\begin{array}{c}\text { Jaring } \\
\text { insang }\end{array}$ & 1 & 2 & 1 & 1 & 7 & 5 \\
\hline $\begin{array}{c}\text { Pukat } \\
\text { cincin }\end{array}$ & 1 & 2 & 1 & 1 & 10 & 4 \\
\hline
\end{tabular}

\section{HASIL DAN PEMBAHASAN}

Perancangan yang dilakukan sebelumnya, maka hasil yang didapat akan dijelaskan pada sub bab mulai tampilan sampai hasil yang di dapat.

\subsection{Menu Perhitungan}

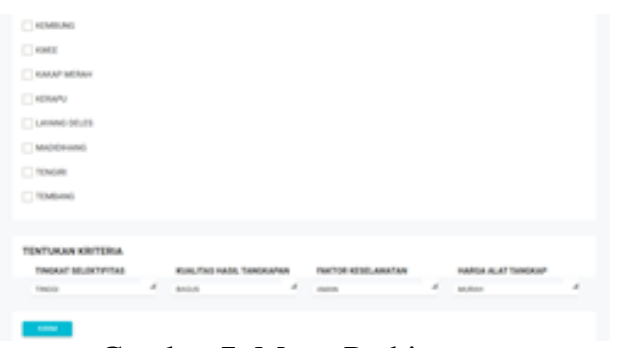

Gambar 7. Menu Perhitungan

Pada menu perhitungan ini pengguna dapat memasukkan bobot kriteria yang di alami sesuai kondisi, dengan memilih ikan yang ingin ditangkap ,tingkat selektifitas, kualitas hasil tangkapan, faktor keamanan dan harga alat tangkap sesuai kondisi yang diinginkan.

\subsection{Hasil Perhitungan Ikan Alu-Alu}

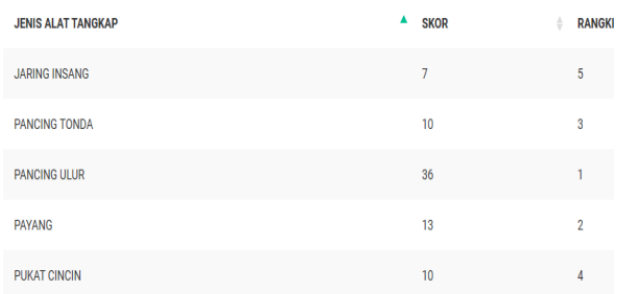

Gambar 5. Halaman perhitungan ikan Alu
Pada halaman perhitungan ikan alu-alu dengan kriteria tingkat selektifitas tinggi, kualitas tangkapan bagus, faktor keamanan aman, dan harga alat tangkap murah di dapat hasil perhitungan sesuai dengan table 7.

\subsection{Hasil Perhitungan Ikan Albakora}

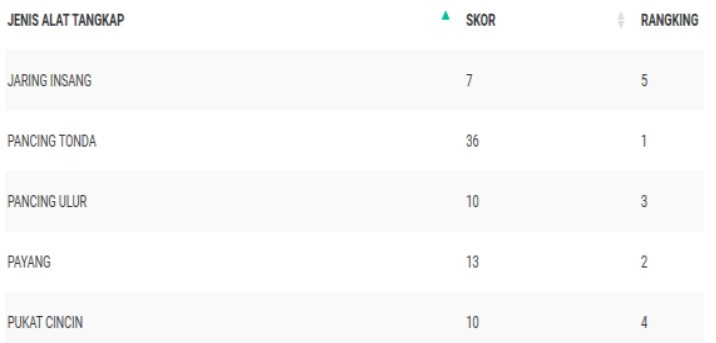

Gambar 6. Halaman perhitungan ikan albakora

Pada halaman ini perhitungan ikan albakora dengan kriteria tingkat selektifitas tinggi, kualitas tangkapan bagus, faktor keamanan aman dan harga murah, hasil perhitungan sesuai dengan table 8 .

\subsection{Pengujian Sistem Browser}

Tabel. 9 Pengujian Sistem Browser

\begin{tabular}{|c|c|c|c|c|}
\hline AKSES & FUNGSI & ME & MF & IE \\
\hline \multirow{5}{*}{ User } & Halaman Utama User & $\checkmark$ & $\checkmark$ & $\checkmark$ \\
\hline & Informasi Ikan & $\checkmark$ & $\checkmark$ & $\checkmark$ \\
\hline & $\begin{array}{l}\text { Informasi Alat tangkap } \\
\text { ikan }\end{array}$ & $\checkmark$ & $\checkmark$ & $\checkmark$ \\
\hline & Penentuan Alat Tangkap & $\checkmark$ & $\checkmark$ & $\checkmark$ \\
\hline & Kontak & $\checkmark$ & $\checkmark$ & $\checkmark$ \\
\hline \multirow{24}{*}{ Admin } & Halaman Login & $\checkmark$ & $\checkmark$ & $\checkmark$ \\
\hline & Halaman Admin & $\checkmark$ & $\checkmark$ & $\checkmark$ \\
\hline & Data Ikan & $\checkmark$ & $\checkmark$ & $\checkmark$ \\
\hline & Edit Data Ikan & $\checkmark$ & $\checkmark$ & $\checkmark$ \\
\hline & Hapus Data Ikan & $\checkmark$ & $\checkmark$ & $\checkmark$ \\
\hline & Data Alat Tangkap & $\checkmark$ & $\checkmark$ & $\checkmark$ \\
\hline & Edit Data Alat Tangkap & $\checkmark$ & $\checkmark$ & $\checkmark$ \\
\hline & $\begin{array}{l}\text { Hapus Data Alat } \\
\text { Tangkap }\end{array}$ & $\checkmark$ & $\checkmark$ & $\checkmark$ \\
\hline & Data Hasil Tangkapan & $\checkmark$ & $\checkmark$ & $\checkmark$ \\
\hline & $\begin{array}{l}\text { Edit Data Hasil } \\
\text { Tangkapan }\end{array}$ & $\checkmark$ & $\checkmark$ & $\checkmark$ \\
\hline & $\begin{array}{l}\text { Hapus Data Hasil } \\
\text { Tangkapan }\end{array}$ & $\checkmark$ & $\checkmark$ & $\checkmark$ \\
\hline & Data Bobot & $\checkmark$ & $\checkmark$ & $\checkmark$ \\
\hline & Ubah data bobot & $\checkmark$ & $\checkmark$ & $\checkmark$ \\
\hline & Hapus data bobot & $\checkmark$ & $\checkmark$ & $\checkmark$ \\
\hline & Data Hasil Admin & $\checkmark$ & $\checkmark$ & $\checkmark$ \\
\hline & Tambah Data Admin & $\checkmark$ & $\checkmark$ & $\checkmark$ \\
\hline & Edit Data Admin & $\checkmark$ & $\checkmark$ & $\checkmark$ \\
\hline & Simpan Data Admin & $\checkmark$ & $\checkmark$ & $\checkmark$ \\
\hline & Hapus Data Admin & $\checkmark$ & $\checkmark$ & $\checkmark$ \\
\hline & $\begin{array}{l}\text { Informasi Alat tangkap } \\
\text { ikan }\end{array}$ & $\checkmark$ & $\checkmark$ & $\checkmark$ \\
\hline & Penentuan Alat Tangkap & $\checkmark$ & $\checkmark$ & $\checkmark$ \\
\hline & Kontak & $\checkmark$ & $\checkmark$ & $\checkmark$ \\
\hline & Halaman Login & $\checkmark$ & $\checkmark$ & $\checkmark$ \\
\hline & Halaman Admin & $\checkmark$ & $\checkmark$ & $\checkmark$ \\
\hline
\end{tabular}

$$
\begin{aligned}
\checkmark & =\text { Berjalan } \\
X & =\text { Tidak berjalan }
\end{aligned}
$$


Pengujian fungsionialitas sitem dilakukan dengan pengujian sistem yang dinyatakan sukses ketika kebutuhan sistem pada tabel 4.1 dapat berjalan sesuai dengan rancangan kebutuhan. Pengujian dilakukan dengan web server xampp v3.2.2 (MF) mozila firefox 63.0.2 (32bit), (ME) Microsoft Edge, dan browser Internet Explorer(IE).

\section{KESIMPULAN DAN SARAN}

\subsection{Kesimpulan}

Adapun kesimpulan yang dapat penulis paparkan setelah melakukan peracangan sistem pendukung keputusan menggunakan metode perbandingan eksponensial antara lain yaitu :

Untuk Pengujian fungsionalitas sistem yang dinyatakan sukses ketika kebutuhan sistem pada tabel 4.1 dapat berjalan sesuai dengan rancangan kebutuhan. Pengujian dilakukan dengan web server xampp v3.2.2 (MF) mozila firefox 63.0.2 (32bit), (GC) google chrome 70.0.3538.110 (64 bit), browser Internet Explorer

\subsection{Saran}

Untuk pengembangan aplikasi yang lebih baik, ada beberapa saran pada aplikasi sistem pendukung keputusan penentuan alat tangkap ikan menggunakan metode perbandingan eksponensial berbasis web yaitu:

1. Diharapkan sistem dapat dikembangkan tidak hanya di Pelabuhan Perikanan Nusantara Prigi.
2. Menambahkan menu kritik dan saran pada aplikasi untuk pengembangan aplikasi selanjutnya agar lebih baik.

\section{DAFTAR PUSTAKA}

[1] Desi Wira Swastika. "Analisis Pendapatan Nelayan Pantai Prigi Desa Tasikmadu Kecamatan Watulimo Kabupaten Trenggalek." Jurnal Ilmu Ekonomi, 2017: 255 - 269.

[2] Diana, S.Si., M.Kom. Metode \& Aplikasi Sistem Pendukung Keputusan. Yogyakarta: Deepublish, 2018.

[3] Heru Lumaksono, Hozairi. "Sistem Pendukung Keputusan untuk Menentukan Alat Tangkap yang Sesuai bagi Nelayan di Madura Menggunakan Metode AHP-TOPSIS." Seminar MASTER 2017 PPNS, 2017: 1 - 10.

[4] Nanda Rilo Prambudi. "FUNGSI TEMPAT PELELANGAN IKAN PELABUHAN NUSANTARA PRIGI DESA TASIKMADU, KECAMATAN WATULIMO, KABUPATEN TRENGGALEK." 2017: 1 - 10.

[5] Nurhayati, Yati. "Implementasi Metode Perbandingan Eskponensial Dalam Penentuan Asisten Laboratorium (Studi Kasus: Di Lab. FKOM UNIKU)." Jurnal Nuansa Informatika, 2015: 1 - 10.

[6] Prof. Dr. Ir. Marimin, M.Sc. Teknik Dan Aplikasi Pengambilan Keputusan Kriteria Majemuk. Bogor: Grasindo, 2004. 